\title{
VERBAL VIOLENCE IN OVERTLY POLITICAL PLAYS BY HAROLD PINTER ${ }^{1}$
}

\begin{abstract}
Although the danger and power of language form the basis of earlier plays by Harold Pinter, they are especially prominent in his dramatic sketch Precisely and overtly political trilogy that will be discussed - One for the Road, Mountain Language and Party Time. We will focus primarily on the author's task to reveal hidden verbal violence that governs individuals in those plays. Each play will be discussed separately suggesting general contexts within which various devices of verbal aggression can be implied. It will be shown that Pinter's characters use words as weapons, while it is ambiguous who the victim/victor is. Language becomes the medium through which characters become dominated and victimized and verbal violence the means of destroying man's individuality.
\end{abstract}

Key words: verbal violence, Pinter, political plays

In the early 1980s, Pinter found himself in a creative stagnation as a result of increased thinking about injustice, lies of state officials, and massive closing of eyes to human rights. Suspicion of authoritarian regimes around the world influenced his works, as early as in his first play The Room. At only twelve, he renounced his family religion, Jewish Orthodoxy, was a member of a teenage group where none of the members "adhered without question to any given to any state of affairs or system of thought" (Billington 2007: 286), opposed the Cold War, and later risked going to jail at the age of eighteen because he had pleaded conscientious objection and refused to join the National Service of the British Army. Therefore, it is no wonder that at the center of the early stage of his dramatic work is the conflict between individual consciousness and the threatening nature of authoritarian groups. In an interview with Billington, a famous critic and biographer, in 1995, he said that "The Dumb Waiter, The Birthday

\footnotetext{
" PhD candidate, Faculty of Philology, University of Belgrade, Studentski trg 3, 11000 Belgrade, Serbia; e-mail: anasitarica1@gmail.com

${ }^{1}$ The paper was written as part of the project 178018 "Social Crises and Contemporary Serbian Literature and Culture: National, Regional, European and Global Framework" of the Ministry of Education, Science and Technological Development of the Republic of Serbia.
} 
Party and The Hothouse are doing something which can only be described as political." (Billington 2007: 287).

Pinter's unmistakable sense of political developments was shaped by his restless conscience, a network of friends from different spheres, and the inevitable influence of public events that led to the creation of so-called "overtly political dramas". In those texts he managed to stir a reader's moral reasoning more directly and more vigorously than in his early plays, and point out the pitfalls of verbal violence. Verbal aggression in overtly political dramatic works that we will deal with in this paper is related to bureaucratic euphemisms (Precisely), human rights violations (One for the Road), oppression of national minorities (Mountain Language), participation of affluent members of society in the violence of the state (Party Time).

Pinter's second wife, Antonia Fraser, said in an interview with Billington that the writer's political opinions and activities were not influenced solely by one ideological or party structure, and that is exactly what is seen in his entire dramatic work:

I would say it's more a rage against social injustice; against any injustice or unfairness. Why does he not protest about China, for example, when he does against the United States? I think it's because he sees that China is rightly perceived as a cruel tyranny whereas we turn a blind eye to US foreign policy; and I think it's the unfairness of that which angers Harold... Harold wouldn't deny Cuba's cruelty towards homosexuals or writers. But I think it's the injustice of the American blockade that angers him. Likewise his feelings about Turkey stem from the fact that we try to pretend it's a nice holiday spot and a member of NATO and so overlook its internal oppressiveness... I think Harold would argue that it's wonderful to be a playwright who can have your plays done all over the world, but the other side of that is that it carries a responsibility to question the nature of particular regimes. (Billington 2007: 288)

Turning to political topics was no longer just an option, as Pinter increasingly felt the need to actively combat injustice and human rights abuses. After a three-year hiatus, the beginning of a new chapter in his dramatic, openly political works will be marked by a dramatic sketch Precisely written for the anti-nuclear show The Big One in December 1983. Precisely promotes life, but it also explores what kind of thinking leads to the notion of "acceptable" death toll from a nuclear attack. ${ }^{2}$ In the text, state

\footnotetext{
${ }^{2}$ At the time when Pinter was writing the sketch, not only did the United Kingdom donate huge sums of money to Trident nuclear missile, but it also allowed large-scale American warheads and explosives to be on the British soil.
} 
officials $^{3}$ Stephen and Roger meet outside the office for a casual meeting and have a drink discussing nuclear war. ${ }^{4}$

\section{STEPHEN}

I mean, we've said it time and time again, haven't we?

ROGER

Of course we have.

STEPHEN

Time and time again. Twenty million. That's what we've said. Time and time again. It's a figure supported by facts. We've done our homework. Twenty million is a fact. When these people say thirty I'll tell you exactly what they're doing - they're distorting the facts. (Pinter 1996: 365)

Stephen is nervous and angry because the supposedly carefully calculated number of dead is being checked. And when Roger says some are talking about a figure of seventy million, Stephen can no longer endure and resort to verbal violence:

You see, what makes this whole business doubly disgusting is that the citizens of this country are behind us. They're ready to go with us on the twenty million basis. They're perfectly happy! And what are they faced with from these bastards? A deliberate attempt to subvert and undermine their security. And their faith. (Pinter 1996: 368)

Roger tries to persuade Steven to increase the number, but to no avail:

\section{STEPHEN}

(Slowly) No, no, Roger. It's twenty million. Dead.

\section{ROGER}

You mean precisely?

STEPHEN

I mean dead. Precisely. (Pinter 1996: 369)

In the anti-nuclear piece, we would expect angry protesters. However, Pinter diverts revolt and resentment at government officials when their mathematical

\footnotetext{
${ }^{3}$ We can infer from their conversation they are the head of ministry, such as officials from the Ministry of Defense, government officials and the like.

${ }^{4}$ They do not directly mention nuclear war but it is very clear from the context.
} 
calculations are called into question. ${ }^{5}$ Stephen says: "I'm going to recommend that they be hung, drawn and quartered. I want to see the color of their entrails" (Pinter 1996: 368). Pinter informs us that the once inconceivable nuclear war is now almost certain, and that there are those who rationally accept its consequences, and use language, that is, verbal violence, skillfully to mask the truth.

In similar light, he continues to develop the theme in One for the Road (1984). In this one-act play, the writer found a way to connect drama and politics - he wrote it in response to what was happening in Turkey at the time: increasing verbal and physical violence against writers, intellectuals and national minorities.

This short play takes place in a sort of a prison, however, the writer does not indicate which country or the governing regime is in question because he wants to emphasize this kind of violence could happen anywhere in the world. Nicolas, a government official, interrogates family members individually, Victor, Gila and their seven-year-old son Nicky. Nicolas is the embodiment of state power and we learn during the course of action that he tortures and eventually mutilates Victor, rapes Gila and kills Nicky. However, Pinter does not explore what we all know - that cruel dictatorship is horrifying, but manages to reach the mind of a man who is, on the one hand, an interrogator, torturer, and abuser, but on the other, one who truly believes in a number of things, and out of that faith is ready to subject his victims to nightmarish verbal and physical violence. Not only is he an evil sadist, but he also acts out of belief in the state, family, religion. The irony is that he destroys the family in the name of patriarchal values. When talking to Billington about this play, Pinter stated: "I believe that reflects, as you know, situations all over the world, under one hat or another now, as then, or at all times. The question of a just cause." (Pinter as quoted in Billington 2007: 294).

Although at first sight confident, Nicolas desperately seeks to justify his actions to those he tortures. At the very beginning of the drama, he asks to bring him a prisoner. Victor enters the room, his clothes are torn, he is bruised. Nicolas orders him to sit down and get up because he immediately wants to show his superiority. Then he belittles Victor's manhood in every sense. As Peter Raby (2009: 69) claims: "many elements are present that seem uncomfortably familiar... but it is the language used by the interrogator, Nicolas, which most disturbs". He gestures with his forefinger and little finger in front of Victor's face and starts an aggressive verbal attack: "Do you think waving fingers in front of people's eyes is silly? I can see your point. You're a man of highest intelligence. But would you take the same view if it was my boot - or my penis?" (Pinter 1996: 373). Nicolas does not threaten openly, but uses harmless

\footnotetext{
${ }^{5}$ Let us recall The Birthday Party and The Hothouse - those who show power and authority are the most insecure.
} 
political words and phrases, and they acquire even more sinister meaning in this context. He repeatedly addresses Victor as a "friend" which is very ironic and can be understood as a threat. He keeps referring to violence and mentions Victor's house: "I hear you have a lovely house. Lots of books. Someone told me that some of my boys kicked it around a bit. Pissed on the rugs, that sort of thing. I wish they wouldn't do that. I do really" (Pinter 1996: 377). Verbal violence is getting more intense, he says he will visit Victor's son later to see how he is, which causes a heightened sense of nervousness in the readers as his words suggest cruelty. Nicolas will then announce death that will occur:

I'm prepared to be frank, as a true friend should. I love death. What about you?

\section{Pause.}

What about you? Do you love death? Not necessarily your own. Others'. The death of others. Do you love the death of others, or at any rate, do you love the death of others as much as I do. (Pinter 1996: 378)

Victor does not respond, and Nicolas continues in his cruelty and talks about Victor's wife Gila. The subtext here strongly suggests that the soldiers have raped her because the torturer says that they all have fallen in love with her, and asks Victor:

You know the old joke? Does she fuck?

Heavily, in another voice:

Does she fuck!

He laughs.

It's ambiguous, of course.

It could mean she fucks like a rabbit or she fucks not at all.

Pause.

Well, we're all God's creatures. Even your wife. (Pinter 1996: 379)

He claims that God speaks through him but then becomes uncertain, "You do respect me, I take it?... I would be right in assuming that?" (Pinter 1996: 375). And again, "Would you like to know me better?" (376). Then, "What do you say? Are we friends?" (378), and "Tell me... truly... are you beginning to love me?" (380). And finally, "I feel a link, you see, a bond. I share a commonwealth of interest. I am not alone. I am not alone!" (381). These are not the words of a mentally strong and independent person, but of a weak man who, somewhat pathetically, boasts of connection with the state and finds solace in it. 
While questioning Victor, Nicolas "confesses":

Ah God, let me confess, let me make a confession to you. I have never been more moved, in the whole of my life, as when - only the other day, last Friday, I believe - the man who runs this country announced to the country: We are all patriots, we are as one, we all share a common heritage. Except you, apparently. (Pinter 1996: 381)

It becomes clear here that Nicolas, like Ben and Gus (The Dumb Waiter) and Goldberg and McCann (The Birthday Party), is just an obedient subject within the system, indicating his vulnerability. Seemingly a play about the cruelty of state officials becomes a complex text about the tortured nature of the torturer.

With each succeeding scene, Pinter reveals the psychological complexity of the seemingly powerful executioner. Nicolas envies Victor everything he has and in order to regain his self-esteem, Nicolas must destroy him. Growing up without maternal love Nicolas cannot understand the bond between a parent and a child 6 , only in the country does he see salvation.

Nicolas is cruelest to Gila verbally torturing her (and later physically) for betraying her father, a former soldier. He asks how she has met her husband, and when she replies that they have met at her father's house, Nicolas starts a verbal attack:

To spawn such a daughter. What a fate.. Oh, poor, perturbed spirit ${ }^{7}$, to be haunted forever by such scum and spittle. How do you dare speak of your father to me? I loved him, as if he were my own father. (Pinter 1996: 389)

After being insulted, when he asks her the same question again, Gila says she has met her husband on the street. She is physically and mentally completely broken and unable to answer Nicolas's question how many times she has been raped. He keeps insisting, waving his fingers in front of her face.

GILA

I don't know.

\section{NICOLAS}

And you consider yourself a reliable witness? (Pinter 1996: 392)

\footnotetext{
${ }^{6}$ In the first scene, he asks Victor: "Do you think I'm mad? My mother did" (Pinter 1996: 373).

${ }^{7}$ Referring to Hamlet: "Rest, rest, perturbed spirit!"
} 
He tells her that she doesn't know how to raise a son ${ }^{8}$ and that he is no longer interested in her, but she will entertain them for a little while before they release her.

In the last scene, Victor appears, neat and well-dressed but his tongue is severed or seriously injured. ${ }^{9}$ Nicholas forces him to drink a glass of whiskey, and Victor somehow manages to say:

\author{
VICTOR mutters. \\ What? \\ VICTOR mutters. \\ What? \\ VICTOR \\ My son. \\ NICOLAS
}

Your son? Oh, don’t worry about him. He was a little prick. (Pinter 1996: 395)

The question arises: who has the power in this last scene. Nicolas still has a state machinery behind him, but Victor shows unwavering resistance and hatred.

Pinter does not deal solely with the subject of physical violence and barbaric torture during interrogation in totalitarian regimes, but violently confronts us with horrible truth and terrific everyday events around the world that go unnoticed. The audience and readers witness only verbal, not physical violence, which confirms the writer's intention to show the consequences of separating language from reality. Pinter does not disclose why Victor, Gila and Nicky are in prison, and suggests that society is slowly becoming a cage under constant Big Brother's scrutiny. This means that if an individual does not have the same opinions, attitudes and beliefs as the ruling regime, the same fate as Victor's awaits him. On the other hand, Pinter offers no definitive answers, there is no resolution in his plays, and Victor's name suggests the steadfastness of his spirit. The writer hopes an individual can still resist sadistic power, and warns us not to be silent before dictatorships, or close our eyes on crimes. Each one of us is responsible to stand in the way of all those who want to impose this or that regime using verbal (and physical) violence as their main weapon.

One year after the premiere of the play One for the Road in London, 1985, Pinter and Arthur Miller went to Turkey for five days as representatives of English and American PEN respectively, to show solidarity with dissident writers. There they spoke to over a hundred intellectuals, former prisoners, diplomats, politicians. They

\footnotetext{
${ }^{8}$ Nicky kicks the soldiers when they break into their house.

${ }^{9}$ Here we can draw a parallel with Stanley from The Birthday Party, who at the end of the drama, appears neat and in a suit after questioning, but cannot say a word.
} 
have collected as many as two thousand three hundred and thirty signatures from writers and scholars demanding respect of human rights. A press conference was held in Istanbul to protest the neglect of human rights in Turkey. Towards the end of their stay, they attended a dinner hosted by the United States ambassador. Pinter could no longer overcome his fury and answered back very angrily the editor of Turkey's largest newspaper. Towards the end of dinner, Pinter and Miller were not formally evicted, but withdrew and left. When they boarded the plane, they learned that they had actually been expelled from the country. All this speaks about Pinter's spirit unwilling to accept worldwide injustice and his struggle for human rights, which he sought to inspire in others through his works and activities.

While in Turkey, Pinter learned firsthand how the ethnic minority, the Kurds, were treated in Turkey (about 15 million of them at the time), and felt the need to shape his response in the best way he could, by writing a drama. This was the birth of Mountain Language.

The writer's dramatic-political activity during the 1980s does not mean he suddenly discovered the need to oppose and replace the mysterious and ambiguous from earlier texts with direct statements. The games of power characterized his work since the beginning of his career as a playwright. However, over time, he became increasingly involved in the public sphere and became aware of the cruelty and hypocrisy of Western democracy, which his conscience could not accept, and in the drama world he saw a way to express justified anger and influence the public. In one interview with Mel Gussow he stated:

I understand your interest in me as a playwright. But I'm more interested in myself as a citizen. We still say we live in free countries, but we damn well better be able to speak freely. And it's our responsibility to say precisely what we think. (Pinter as quoted in Billington 2007: 303)

Pinter believed it was his responsibility to speak the unpleasant truth and protest against the state of society. He now saw it as a duty to expose the lies by which we defined our lives, as well as the subtle verbal violence in the discourse of state officials, politicians and diplomats.

Concerned about the growing intolerance, intellectual conformism and lack of political debate in the United Kingdom, Pinter and Antonia Fraser decided to host private discussions where writers, mostly opponents of Margaret Thatcher's policy, gathered. ${ }^{10}$ They were named June 20th Society, since the first meeting was held on June 20, 1988, when political journalist Anthony Howard gave a speech about the

\footnotetext{
${ }^{10}$ During the tenure of Margaret Thatcher, Pinter expressed a growing concern about what he thought was civil liberty - the right to free speech, belief and information.
} 
diminishing activity of leftists and the unthinkable victory of Labourists. There was a debate among participants such as Salman Rushdie, Margaret Drabble, David Hare and others. Pinter's intention was never to form a protest group, but the sole aim was to allow discussions on the state of society. However, soon reporters and photographers started arriving outside his house during meetings. The media reported on the meetings of this society through mockery and contempt and called them "champagne socialists" (Billington 2007: 308). In a healthy society, such a private gathering would be regarded as a valid and laudable activity of intellectuals, demonstrating how intolerant the United Kingdom was during the 1980s. Soon, this group was destroyed by publicity. Ironically, exactly what led to their formation - media triviality and intellectual intolerance - led to the cessation of June 20th Society.

Pinter shaped his response to all of these events in Mountain Language, which premiered in 1988. He began writing this drama in 1985 after visiting Turkey and witnessing a violent ban on using Kurdish, and finished it under the influence of what was happening in his country. In an interview with Mel Gussow, he stated:

From my point of view, the play is about suppression of language and the loss of freedom of expression. I feel therefore it is as relevant in England as in Turkey. A number of Kurds have said that the play touches them and their lives. But I believe it also reflects what's happening in England today - the suppression of ideas, speech and thought. (Pinter as quoted in Billington 2007: 309)

In the play Mountain Language, Pinter confronts us with the fact that there is no longer a distinction between Them and Us; among tyrannies and supposedly superior Western democracies. This text offers us a somber insight of suppression and prohibition of opinions that oppose the ruling regime. It also reminds us that people have an urge to ban, deny and negate everything they cannot understand. It is not a documentary drama but an expression of the writer's fears for his people. Through it, as if we could hear the question: how long does it take to become the anti-democratic society so readily and swiftly condemned? ${ }^{11}$

The play takes place in four scenes, in a creepy camp/prison. In the first scene, in front of the prison wall, the Young and the Elderly Women ${ }^{12}$ wait to visit their husband/

\footnotetext{
${ }^{11}$ At the time when Pinter was writing this drama, the United Kingdom was marked by several events including a restriction on victim's right to remain silent, the anti-homosexual Clause 28, a ban on trade unions, a raid on a journalist's house and a BBC television editorial board to stave off anything to do with Secret Society TV series.

${ }^{12}$ For the first time in Pinter's plays, the characters have no names but are: Young Woman, Elderly Woman, Sergeant, Officer, Guard, Prisoner, Hooded Man and Second Guard.
} 
son. While waiting, the Sergeant and the Officer verbally torture them. The Young and the Elderly Woman have been waiting for eight hours in the snow to see the prisoner and the Elderly Woman's thumb has been bitten by a dog so it hangs loosely like it is about to fall off; the Young Woman complains about this to the guards. Instead of protecting and helping them, the Officer insults them, threatens and absurdly insists they tell him the name of the dog that bit the Elderly Woman. Then, the Sergeant comes, who is even more cruel than the Officer and speaks:

Your husbands, your sons, your fathers, these men you have been waiting to see, are shithouses. They are enemies of the State. They are shithouses. (Pinter 1996: 403)

The Officer then points out they are mountain people and their language is forbidden:

Now hear this. You are mountain people. You hear me? Your language id dead. It is forbidden. It is not permitted to speak your mountain language in this place. You cannot speak your language to your men. It is not permitted. Do you understand? You may not speak it? It is outlawed. You may only speak the language of the capital. That is the only language permitted in this place. You will be badly punished if you attempt to speak your mountain language in this place. This is a military decree. It is the law. Your language is forbidden. It is dead. No one is allowed to speak your language. Your language no longer exist. Any questions? (Pinter 1996: 403)

The Young Woman hands them correct documents, they say her husband is imprisoned in the wrong place because he is not a mountain person, but they continue to humiliate and insult her and eventually call her a "fucking intellectual" (Pinter 1996: 404).

In the second scene, in the Visitors Room, the Elderly Woman tries to speak to her son but the Guard interrupts her immediately because she speaks forbidden, mountain language, though she knows no other language. The Guard is on the phone because he wants to report the inmate's misconduct, however, the only thing the inmate has said is that he has a wife and three children, and it is not clear why that is the reason to report him. Then, the lights suddenly dim and readers can hear recorded voices while the Elderly Woman and her son sit in silence. Pinter wants to show that a language is the oppressor's means of torture, but it is also a salvation for victims. As 
they hear nothing, the guards believe they have complete control over what happens, but the writer suggests people can reach each other through language in their minds.

In the third scene, titled "Voices in the Darkness", the Young Woman enters the wrong door, and the Sergeant insults her. When he hears that she is the wife of the Hooded Man, they sneer at him because he is in the same room. Then again we hear recorded conversation between the Young Woman and her husband, the lights dim, and when the room is fully lit again, the Hooded Man falls to the floor. The Sergeant tells the Young Woman that if she wants to get information about the place and the prisoners, she can come on Tuesday and find a person named Joseph Dokes. She then speaks the Sergeant's language:

Can I fuck him? If I fuck him, will everything be all right?

\section{SERGEANT}

Sure. No problem. (Pinter 1996: 411)

The last scene is in the Visitors Room where the Elderly Woman sits against a son whose face has been bloodied and his whole body shakes. The Guard informs them, "Oh, I forgot to tell you. They've changed the rules. She can speak. He can speak in her own language. Until further notice" (Pinter 1996: 412). Her son says that to her, but the Elderly Woman does not respond. He begs her to speak and eventually falls to the floor, breathing heavily and shaking. The Sergeant comes in and says: "Look at this. You go out of your way to give them a helping hand and they fuck it up." (Pinter 1996: 414). This is very sarcastic and represents the ultimate form of verbal violence because the powerful apparently succeeded in banning the mountain language. Quigley's (1974: 414) conclusion of The Dwarfs ${ }^{13}$ can be applied equally well to Mountain Language: "Linguistic control it seems, is the ultimate power in this play. To control what someone is able to say is to control to a considerable extent what they are able to be." Like Stanley in The Birthday Party after Goldberg and McCann's interrogation or Victor's in the drama One for the Road, the Elderly Woman is metaphorically crippled, unable to speak anymore, and the inability to speak becomes a symbol of the destruction of language, the loss of self, the breakdown of individual's spirit and the creation of obedient subjects of a regime.

This becomes a dramatic piece about the suppression and prohibition of diversity in favor of the centralised culture and the image of society where any indication of dislike of majority is seen as a threat. As Mary Luckhurst (2009: 115) points out, the denial of the right to speak a language becomes "legitimised state torture and

\footnotetext{
${ }^{13}$ Another play by Harold Pinter, published in 1990.
} 
symbolically marks the beginning of genocide". Precisely because Pinter does not portray an alien, isolated world, but faithfully depicts the world we live in and tells us scenes like this can happen anywhere (if they have not already happened), this, at times unbearable drama, is of great importance. It awakens the readers' consciousness and emotions and urges them to open their eyes and not allow themselves to be another victim of verbal violence of the ruling elite.

In addition to the dominant theme of separating language from reality in the upcoming drama Party Time, Pinter shows concern over society's indifference to atrocities committed in the name of "law and order". This is also the last drama in a trilogy of short dramatic texts on the subject of state repression. At the heart of this piece, unlike the previous two dramas where we see torturers and victims, here we have elegantly dressed, isolated as in a vacuum, wealthy individuals cut off from the harsh reality of the outside world. Once again, the writer manages to shake our moral reasoning and conscience by telling us openly the class of "privileged" goes hand in hand with the increasingly powerful state and that our lives are more and more governed by "narcissistic materialism" (Billington 2007: 330) where it is not acceptable to react to injustice and corruption. Considering this, it is not surprising that after its premiere in 1991, newspaper critics in newspapers such as the Independent, the Financial Times and the Daily Telegraph, once again scorned Pinter's drama. Unable to look the truth in the eyes they could only severely criticize Party Time.

The setting, as it is common in Pinter's plays, is not mentioned because the writer wants to indicate that what happens in the drama is not a picture of one country but happens around the world; although the context strongly suggests it is set in London. ${ }^{14}$ The host of the party, Gavin, is a high-ranking state official ${ }^{15}$ responsible for street riots and blockades that have made some of his affluent guests unable to get through easily and get there in time for the party. ${ }^{16}$ His guests are also members of an exclusive new health club, and enthusiastically comment its "fantastic" warm towels (Pinter 1996: 428), "wonderful” lighting (430) and "brilliant" cannelloni (431).

\footnotetext{
${ }^{14}$ Melissa is addressed as "Dame" when she comes to the party and this is specifically British chivalry title given to a woman of high rank; Dusty is also indicative referring to dust, thus implying she will have the same fate as her brother Jimmy; and Jimmy may suggest Jimmy Porter, first angry young man from kitchen-sink drama Look Back in Anger by another English playwright, John Osborne. Jimmy Porter is an outcast as he is a threat to the ruling ideology similar to many Pinter's characters.

${ }^{15}$ Terry mentions Gavin is "an honorary member" (Pinter 1996: 429) of a health club.

${ }^{16}$ Melissa comments, “The town's dead. There's nobody on the streets, there's not a soul in sight, apart from some... soldiers. My driver had to stop at a... you know... what do you call it?... a roadblock. We had to say who we were... it really was a trifle..." (Pinter 431-432). She does not want to talk about what she has seen on the streets, the truth is too painful, and it is easier and preferable for her to isolate herself with others in the world of privileged (Alfirević 2017: 136). Her omission of words in sentences indicates that she does not want to see and name what really happens.
} 
The club also becomes a metaphor for "right-wing, conservative political ideology"17 (Alfirević 2017: 136). They gossip and brag about their luxury summer vacations. However, these pretentious and vain conversations of gallant and sophisticated guests only mask verbal aggression. Charlotte and Liz talk about a man Liz has fallen in love with and his girlfriend:

\section{LIZ}

He looked at me.

\section{CHARLOTTE}

Did he?

\section{LIZ}

I swear it. As he was being lugged out he looked back, I swear, at me, like a wounded deer, I shall never, as long as I live, forget it, I shall never forget that look.

\section{CHARLOTTE}

How beautiful.

\section{LIZ}

I could have cut her throat, that nymphomaniac slut.

\section{That bigtitted tart -}

\section{CHARLOTTE}

Raped the man you love. (Pinter 1996: 434-435)

Verbal violence implies physical violence in the conversation between Fred and Douglas:

\section{FRED}

I admire people like you.

\section{DOUGLAS}

So do I.

FRED clenches his fist.

\footnotetext{
${ }^{17}$ Terry says: "Mind you, there's a waiting list as long as - I mean you've got to be proposed and seconded, and then they've got to check you out, they don't let any old spare bugger in these, why should they?" (Pinter 1996: 429).
} 
FRED

A bit of that.

DOUGLAS clenches his fist.

DOUGLAS

A bit of that

\section{DOUGLAS}

We want peace and we're going to get it. But we want that peace to be cast iron. No leaks. No draughts. Cast iron. Tight as a drum. That's the kind of peace we want and that's the kind of peace we're going to get. A cast-iron peace. (Pinter 1996: 436-437)

Melissa talks about tennis and swimming clubs from her youth and claims they were closed because they lacked "moral foundation" (Pinter 1996: 454). She continues; "But our club, our club - is a club which is activated, which is inspired by a moral sense, a moral awareness, a set of moral values which is - I have to say unshakeable, rigorous, fundamental, constant" (Pinter 1996: 454).

We also hear verbal violence in Dusty and Terry's conversation, and Terry reveals he is ready to kill members of his own family if they dare question the correctness of state decisions.

\section{DUSTY}

Perhaps you'll kill me when we get home?...

How are you going to do it? Tell me.

\section{TERRY}

Easy. We've got dozens of options. We could suffocate every single one of you at a given signal or we could shove a broomstick up each individual arse at another given signal or we could poison all the mother's milk in the world so that every baby would drop dead before it opened its perverted bloody mouth.

\section{DUSTY}

But you still love me?

TERRY

Of course I love you. You're the mother of my children. (Pinter 1996: 445-446) 
The only thing that interrupts this "harmonious" atmosphere of the complacent group is the argument between Terry ${ }^{18}$ and his wife Dusty, as she does not stop questioning him about what has happened to her missing brother Jimmy. Terry threatens her not to ask such questions, and everything is clarified at the end of the drama when a beam of bright light enters the room and intermittently illuminates the tormented Jimmy, a victim of state cruelty who has been rejected by party guests. He is, as Richard A. Cave (2009: 139) concludes: "the reality, the product, the true cultural expression of the political elite, whom we see elsewhere in the play vacuously partying to celebrate their supposed superiority and absolute right to rule".

At the end of the party Gavin gives a speech:

.... This round-up is coming to an end. In fact, normal services will be resumed shortly. That is, after all. Our aim. Normal service. We, if you like, insist on it. We will insist on it. We do. That's all we ask, that the service this country provides will run on normal, secure and legitimate paths and that the ordinary citizen be allowed to pursue his labours and his leisure in peace. Thank you all so much for coming here tonight. It's been really lovely to see you, quite smashing. (Pinter 1996: 455)

The aforementioned "services" obviously refer to law enforcement through physical violence, and what is "normal" to him is, in fact, inhumane and deadly.

One of few critics, Irving Wardle, got to the core of this drama when he told in the Independent on Sunday that: "the play reflects the reported iniquities of Africa and Latin America in the perspective of a London that Pinter knows inside out" (as quoted in Billington 2017: 331). However, Pinter does not directly say it is London, but rather shows that one of the preconditions of fascism - the elite completely uninterested in the decisions made on its behalf - is becoming recognized in the United Kingdom. He goes one step further and points out that beneath that salon elegance and luxury lies verbal violence as a means of total control over individuals. In this context, the phrase "agenda" has a sinister meaning. At one point, Terry will answer Dusty's question and tells her that Jimmy is "not on anyone's agenda" (Pinter 1996: 440). She will defiantly answer him twice that he is on her agenda, and Terry's verbal violence intensifies: "No, no, you've got it wrong there, old darling. What you've got wrong there, old darling, what you've got totally wrong, is that you don't have any agenda. Got it? You have no agenda. Absolutely the opposite is the case. (To the others.) I'm going to have to give her a real talking to when I get her home, I can see that" (Pinter 1996: 441). The word of neutral connotation then becomes a euphemism for a violent political action.

\footnotetext{
${ }^{18}$ Who is employed to carry out the dirty work for his boss.
} 
Similarly, from the conversation between Charlotte and her former lover, we conclude that her husband, whose death was slow and quick ${ }^{19}$, was an enemy of the

${ }^{19}$ FRED

You said your husband died.

CHARLOTTE

My what?

FRED

Your husband.

CHARLOTTE

Oh my husband. Oh yes. That's right. He died.

FRED

Was it a long illness?

CHARLOTTE

Short.

FRED

Ah.

Pause.

Quick then.

CHARLOTTE

Quick, yes. Short and quick.

Pause.

FRED

Better that way.

CHARLOTTE

Really?

FRED

I would have thought.

CHARLOTTE

Ah. I see. Yes.

Pause.

Better for who?

FRED

What?

CHARLOTTE

You said it would be better. Better for who?

FRED

For you.

CHARLOTTE laughs.

Yes! I'm glad you didn't say him.

FRED

Well, I could say him. A quick death must be better than a slow one. It stands to reason.

CHARLOTTE

No it doesn't.

Pause.

Anyway, I'll bet it can be quick and slow at the same time. I bet it can. I bet death can be both things at the same time. Oh by the way, he wasn't ill. (Pinter 1996: 448-450) 
state and a victim of torture, and when Fred warns her to "leave the streets to us" (Pinter 1996: 450), she realizes that he too has been involved in her husband's death. Staring at him, she asks, "God, your looks! No, seriously. You're still so handsome! How do you do it? What is your diet? What is your regime? What is your regime by the way?...." Suddenly, the word "regime" like the word "agenda" has a tragic connotation.

The drama Party Time faithfully portrays a hermetic, reckless society so preoccupied with self-interest that it is completely indifferent to civil rights and freedom. Members of the elite enjoy the club, and those who break the rules of this society are despised and Terry declares: "And if they do we kick them in the balls and chuck them down the stairs with no trouble at all." (Pinter 1996: 453). Pinter warns that accepting someone else's suffering and oppression in the name of order and stability is morally unforgivable.

From the dramatic sketch Precisely to the trilogy One for the Road, Mountain Language and Party Time, Pinter's preoccupation with the struggle between an isolated individual and a menacing outside world gets concrete outlines - the powerless individual and the state system are now opposed. Unspecified threat no longer penetrates the world of the room, abusers and torturers have long since forcibly opened the door and occupied the once safe space. Physical violence is not shown because verbal violence has become more dangerous. Goldberg and McCann's verbal aggression from The Birthday Party has spread and infected every part of modern society. Verbal abuse of Riley in The Room, metaphorical mutilation, or silencing Stanley in The Birthday Party, Lamb in The Hothouse, Gus in The Dumb Waiter, Aston in The Caretaker, Victor in One for the Road, the Elderly Woman in Mountain Language, Jimmy in Party Time, represent proof that Pinter moved from the topic of unspecified danger to openly political threat, while depicting language as a means of oppression and torture. The writer confronts the audience and readers with a group of people no different than themselves, warns us not to close our eyes to verbal violence and stresses the importance of finding the urge to oppose it.

\section{References}

Alfirević, A. (2017). Kazalište okrutnosti Harolda Pintera. Zagreb: Filozofski fakultet. Billington, M. (2007). Harold Pinter. London: Faber and Faber.

Cave, R. A. (2009). Body Language in Pinter's Plays. In: P. Raby (ed.), The Cambridge Companion to Harold Pinter, Cambridge: Cambridge University Press, 123-146. 
Luckhurst, M. (2009). Speaking Out: Harold Pinter and Freedom of Expression. In: P. Raby (ed.), The Cambridge Companion to Harold Pinter, Cambridge: Cambridge University Press, 105-121.

Pinter, H. (1996). Harold Pinter Plays Four. London: Faber and Faber.

Quigley, A. E. (1974). The Dwarfs: A Study in Linguistic Dwarfism. Modern Drama 17(4), 413-422.

Raby, P. (2009). Tales of the City: Some Places and Voices in Pinter's Plays. In: P. Raby (ed.), The Cambridge Companion to Harold Pinter, Cambridge: Cambridge University Press, 56-74.

Shakespeare, W. The Tragedy of Hamlet, Prince of Denmark. (3 September 2019) $<\mathrm{http}: / /$ shakespeare.mit.edu/hamlet/full.html $>$. 